\title{
Micronutrient Content and Total Lactic Acid Bacteria of Dadiah Pudding as Food Supplementation for Pregnant Women
}

\author{
Zuhrah Taufiqa ${ }^{1,2}$, Dian Novita Chandra ${ }^{3}$, Helmizar Helmizar ${ }^{4}$, Nur Indrawaty Lipoeto ${ }^{5}$, Badriul Hegar ${ }^{6 *}$ \\ ${ }^{1}$ Department of Nutrition, Doctoral Program, Faculty of Medicine, Universitas Indonesia, Jakarta, 10430, Indonesia; ${ }^{2}$ Medical \\ Education Unit, Faculty of Medicine, Universitas Andalas, Padang, 25144, Indonesia; ${ }^{3}$ Department of Nutrition, Faculty of \\ Medicine, Universitas Indonesia, Cipto Mangunkusumo Hospital, Jakarta, 10430, Indonesia; ${ }^{4}$ Department of Nutrition, \\ Faculty of Public Health, Universitas Andalas, Padang, 25144, Indonesia; ${ }^{5}$ Department of Nutrition, Faculty of Medicine, \\ Universitas Andalas, Padang, 25144, Indonesia; ${ }^{6}$ Department of Pediatrics, Faculty of Medicine, Universitas Indonesia, Cipto \\ Mangunkusumo Hospital, Jakarta, 10430, Indonesia
}

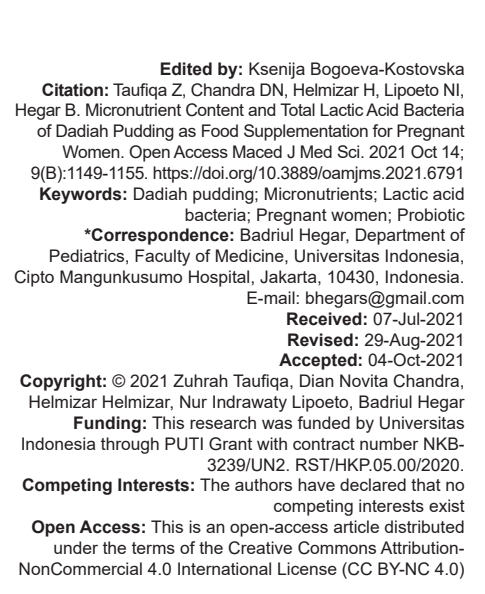

Abstract

BACKGROUND: Dadiah, traditional yogurt from Indonesia, which is known as a source of probiotics, also contains micronutrients

AIM: This descriptive study aimed to determine whether additional ingredients and processes during the manufacture of Dadiah pudding maintain the iron, zinc, calcium, and total lactic acid bacteria (LAB) contents.

METHODS: Dadiah pudding was made using Dadiah originated from Bukittinggi, West Sumatra. Micronutrient levels were analyzed according to Indonesian National Standard 01-2896-1998. The total LAB were counted by inoculating samples on Man, Rogosa, and Sharpe agar with serial dilution, and morphological identification was carried out using gram stain

RESULTS: In $100 \mathrm{~g}$ of original Dadiah, mango and chocolate Dadiah pudding contained 347.98, 276.61, and 279.29 $\mathrm{mg}$ of calcium; 4.87, 3.75, and $6.31 \mathrm{mg}$ of zinc; $6.53,6.60$, and $9.39 \mathrm{mg}$ of iron; and $6.4 \times 10^{\circ}, 6.1 \times 10^{9}$, and $2.4 \times$ $10^{\circ} \mathrm{CFU} / \mathrm{ml} \mathrm{LAB}$, respectively.

CONCLUSION: This study found that modifying the original Dadiah into Dadiah pudding has been proved to affect the concentration of calcium, zinc, and iron and to maintain total LAB. We suggest that consuming Dadiah pudding may be a good choice as a food supplementation for pregnant women to optimize the golden period outcomes.

\section{Introduction}

The first 1000 days of a child's life are a golden period for child growth and development. Maternal nutritional adequacy is positively associated with birth outcomes. In general, poor nutrition during pregnancy caused micronutrient deficiency [1]. Low intake of calories and some micronutrients such as iron and zinc during pregnancy can result in low birth weight [2], [3], [4]), the major determinant for stunted growth [5]. Iron and calcium deficiency in pregnant women also increased the risk of preterm birth, which led to early neonatal and infant mortality [2], [6]. Many women go through their entire pregnancy without reaching the minimum required intake of these micronutrients [7], [8], [9]. Undernutrition of a child in the first 2 years also correlated with the immaturity of gut microbiota [10], [11]. Up to $20 \%$ of stunting was thought to occur in the uterus. New evidence has found that there are host-microbial interactions in the uterus and that the fetus can inherit maternal microbes before birth [12], [13]. Probiotic administration during pregnancy affected the gut microbiota of the mother [14]. Dietary intake makes up more than $20 \%$ of gut microbiota variations in humans [15] and micronutrients act as an ecological modulator of intestinal microbes [16].

Dadiah or "Dadih," a yogurt-like product that fermented from West Sumatran swamp buffalo's milk is used as a bottom-up approach to tackling the undernutrition problem. Although the manufacturing of Dadiah is still in a traditional process and has not met any national standards [17] or international standards [18] for yogurt and fermented milk, Dadiah provides safety and health for people who consume it. There are no pathogenic bacteria in Dadiah [19]. Several studies had demonstrated that Dadiah had beneficial effects on the intestinal health of mothers and children due to its nutritional value and its role as a probiotic [19], [20], [21], [22], [23], [24]. Dadiah had more calories than yogurt from cow's milk [19]. Dadiah also contains micronutrients such as calcium, iodine, zinc [25], and several B vitamins and riboflavin, niacin, and folic acid [26]. Different 
sources of Dadiah had different amounts of macroand micronutrients content [19], [27]. Different regions of buffalo's milk source, as a probiotic product, also caused different numbers of viable lactic acid bacteria (LAB) [29], [20], [28]. LAB produced various kinds of enzymes that play a role in host metabolism and make Dadiah easier to digest than raw fresh buffalo milk [29].

Dadiah is typically consumed by West Sumatran people as one of ethnic foods of the Minangkabau culture. It was served originally with rice by adding sliced shallot and red chilies, mixed with sticky rice and palm sugar as "ketan dadiah" or with traditional glutinous rice flakes called "ampiang dadiah." The shelf life of the original Dadiah was only 3 days at room temperature with optimum growth of LAB and nutrient value; it was $48 \mathrm{~h}$ at $20^{\circ} \mathrm{C}-45^{\circ} \mathrm{C}$ [29]. Dadiah stored at $8^{\circ} \mathrm{C}$ temperature was longer in duration, 6-12 days. Lower temperature can slow down the fermentation process and thus prevent the metabolic activity of pathogen bacteria and inhibit fungal growth [30]. Sensory test results indicated that different regions resulted in differences in color, taste, texture, and general acceptance of Dadiah. Panelists preferred Dadiah that originated from Tanah Datar with a slightly white color, less acidic taste, and a soft texture like that of a pudding than Dadiah from Agam [19]. Therefore, Dadiah is now also made into Dadiah pudding, which is served as a cold snack for pregnant women in West Sumatra [31]. Storing the Dadiah pudding at a lower temperature made the shelf life longer than that of the original Dadiah [32]. Dadiah pudding may also be more tolerant for consumption due to its lower acidity and aroma than those of original Dadiah. However, it is not yet known whether the micronutrient content and total LAB in the Dadiah pudding and the addition of ingredients and the manufacturing process during making of Dadiah pudding will affect the micronutrient content and $L A B$ growth in Dadiah. This research also modified the ingredients and processes in manufacturing Dadiah pudding in Helmizar's previous study [31] to get more optimal results. Moreover, data on micronutrient intake for pregnant women in West Sumatra is still limited. Compared to the other studies, this is the first study that investigates the micronutrient contents in Dadiah pudding. This study aims to determine the micronutrient content and total LAB in Dadiah and Dadiah pudding from Bukittinggi, West Sumatra in relation to fulfill micronutrient intake of pregnant women in the province by giving local food.

\section{Materials and Methods}

\section{Materials}

Dadiah samples (Figure 1) were taken from a village of Gaduik region, Bukittinggi, West Sumatra. Dadiah was made in the traditional way without being boiled, pasteurized, or inoculated with a starter culture. Fresh unheated buffalo milk was poured into a bamboo tube and then covered with banana leaves or plastics. It was incubated at room temperature $\left(28^{\circ} \mathrm{C}-30^{\circ} \mathrm{C}\right)$ for $48 \mathrm{~h}$ to allow natural fermentation. Original Dadiah has a cream-white color, smooth consistency, shiny surface, delicious aroma, and sour taste [29].

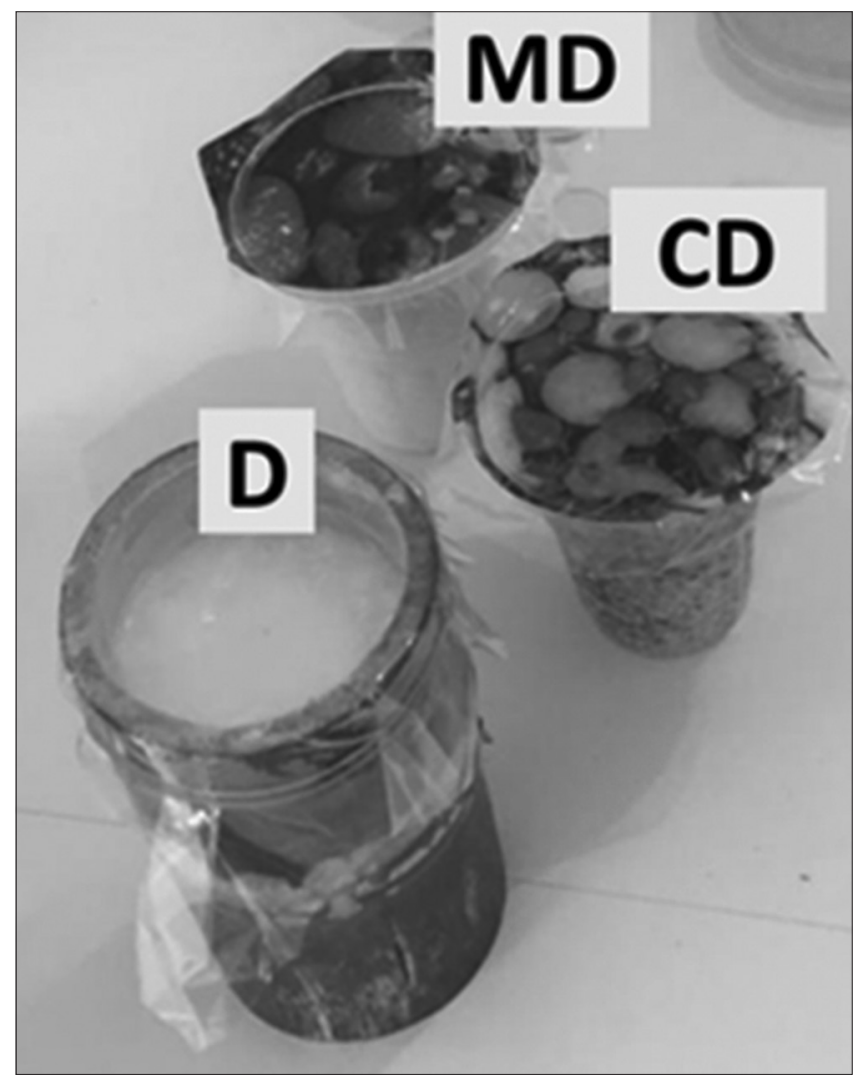

Figure 1: $D$ (Dadiah), MD (Mango Dadiah), and CD (Chocolate Dadiah)

Dadiah pudding was made by modifying a recipe from Helmizar [31]. There were two flavors of Dadiah pudding: Mango and chocolate (Figure 1). The ingredients used in this study are $75 \mathrm{~g}$ of 48-h fermented buffalo's milk, $15 \mathrm{~g}$ of pudding powder (Nutrijel pudding of mango milk or chocolate produced by PT Forisa Nusapersada with BPOM RI MD 663310235304), and $50 \mathrm{ml}$ of water. By contrast, previous research used $75 \mathrm{~g}$ of 24-h fermented buffalo's milk mixed with $5 \mathrm{~g}$ Dadiah as a starter, $15 \mathrm{~g}$ of pudding powder, and $50 \mathrm{ml}$ of water [31]. Thus, there was no starter used in making Dadiah pudding in this study. Pudding powder was mixed with the water, and the mixture was cooked and stirred until it boiled. Pudding was cooled at room temperature to $\pm 60^{\circ} \mathrm{C}-70^{\circ} \mathrm{C}$ and then mixed well with Dadiah. Dadiah pudding was poured into molds, chilled in a refrigerator for it to be ready to be served.

\section{Maternal intake of micronutrients}

This research was part of a randomized, doubleblind, and controlled trial, "The Effect of Dadiah on 
Pregnant Women and Birth Outcome in West Sumatra," conducted with 208 pregnant women in Agam, Lintau, and Padang Panjang, West Sumatra, Indonesia during 2018-2020. The subjects were healthy pregnant women aged 17-44 years who were in the first two trimesters of pregnancy and had registered for antenatal care examination at the selected Primary Health Centers in 2018-2020. They gave their consent to participate in this study. Pregnant women with a previous diagnosis of HIVIAIDS, TBC, hepatitis B, multiple pregnancies, high-risk pregnancies (hypertension, preeclampsia, diabetes, and history of bleeding) were excluded from the study. Maternal intake of calcium, zinc, and iron during the first trimester was assessed using the validated Minang semi-quantitative food frequency questionnaire developed by Lipoeto [33]. Data were managed and analyzed descriptively using IBM SPSS Statistics for Windows (SPSS) version 20.0 (IBM, Armonk, New York) and presented as tables.

\section{Micronutrients analysis}

The calcium, zinc, and iron levels were tested at Industrial Research and Standardization Center (Baristand) Laboratory, Padang, West Sumatra according to Indonesian National Standard (SNI) 01-2896-1998.

\section{Macroscopic and total LAB count}

De Man, Rogosa, and Sharpe (MRS) Agar (Oxoid, Thermo Fisher Scientific, Hampshire, UK) media, distilled water, and required materials were prepared. The research was conducted at the Microbiology Laboratory of the Faculty of Medicine, Universitas Andalas. For an initial $10^{-1}$ dilution, a total of $100 \mu$ of each sample was dissolved in $900 \mu$ l distilled water in a test tube, the solution was vortexed until it was homogeneous. This procedure was repeated until the $10^{-6}$ dilution was attained. From the appropriate dilution $\left(10^{-5}-10^{-6}\right)$, a $100 \mu \mathrm{l}$ sample was taken and inoculated on a Petri dish containing MRS agar media and then flattened with a sterilized hockey stick. The inoculum was placed into the anaerobic jar and incubated for $48 \mathrm{~h}$ at $37^{\circ} \mathrm{C}$. There were three Petri dishes marked as codes D for Dadiah, CD for chocolate Dadiah pudding, and MD for mango Dadiah pudding. After $48 \mathrm{~h}$, the growing colonies of LAB were observed as white-beige smooth round. The number of $\mathrm{LAB}$ colonies was expressed as colony-forming units per milliliter of sample and calculated using the formula (1).

$\mathrm{CFU} / \mathrm{ml}=$ number of colonies $\times 1 /$ dilution $\times 1 /$ sample weight

\section{Morphological identification}

Bacterial culture colonies were taken and placed on a microscopic slide. The crystal violet dye was applied to a heat-resistant smear and left for $1 \mathrm{~min}$. Then, it was rinsed with distilled water and dried with air, followed by dropping of iodine, allowed to react for 1-2 min, and rapid decolorization with ethanol. Finally, $X$ was counterstained with safranin for $1 \mathrm{~min}$ and a rinse with distilled water and air-dried. The results were observed under a microscope at $1000 \times$ magnification.

\section{Results and Discussion}

\section{Maternal intake of micronutrients}

The subjects comprised 208 healthy pregnant women whose mean values of age and gestational age were $29.28 \pm 5.42$ years and $13.60 \pm 4.14$ weeks, respectively. Our study revealed that more than half of pregnant women had inadequate intakes of calcium (89.9\%), zinc $(69.7 \%)$, and iron $(74.0 \%)$. The inadequacy of dietary intake of these micronutrients as compared to the Indonesian Recommended Dietary Allowances (RDAs) is indicated in Table 1.

Table 1: Daily micronutrient intake of subjects

\begin{tabular}{llllll}
\hline Variable & Mean (SD) & Median & Min.-Max. & RDA & \% RDA \\
\hline Calcium $(\mathrm{mg})$ & $562.70(355.35)$ & 457.43 & $109.60-2328.59$ & 1,300 & 43.3 \\
Zinc $(\mathrm{mg})$ & $8.22(3.59)$ & 7.39 & $2.42-21.78$ & 12 & 68.5 \\
Iron $(\mathrm{mg})$ & $15.99(5.80)$ & 15.44 & $4.81-31.62$ & 26 & 61.5 \\
\hline SD: Standard deviation; RDA: Recommended dietary allowance for Indonesian pregnant women aged \\
16-49 years.
\end{tabular}

The daily mean and percentage of RDAs consumed for calcium intake in this study were lower than those in a previous study on 203 Minangkabau pregnant women above 28 weeks of pregnancy in two coastal districts (Pariaman and Pasaman Barat) and two mountainous areas (Solok and Tanah Datar) [7]. However, these results were higher than those of previous research by Bardosono [8] on maternal micronutrient deficiency during the first trimester among 143 pregnant women living in Jakarta. This may be caused by nausea as the most $(70.6 \%)$ reported complaints found among the participants related to early pregnancy [8]. Based on this evidence, pregnant women went through the first trimester without attaining the minimum required intake of these micronutrients that need further intervention to plan a healthy pregnancy outcome.

\section{Micronutrient analysis}

According to the Indonesian RDA, pregnant mothers aged 16-49 years need approximately $1300 \mathrm{mg}$ of calcium, $12 \mathrm{mg}$ of zinc, and $26 \mathrm{mg}$ of iron daily [34]. Table 2 presents concentrations of calcium, zinc, and iron in Dadiah and Dadiah pudding obtained in this study. There were $347.98 \mathrm{mg}$ of calcium (Ca), $4.87 \mathrm{mg}$ of zinc $(\mathrm{Zn})$, and $6.53 \mathrm{mg}$ of iron (Fe) in $100 \mathrm{mg}$ of Dadiah (D) from Gaduik, Bukittinggi. Consumption 
of the original Dadiah in this study by the mother during pregnancy may cover approximately one-third of calcium, two-fifth of zinc, and one-fourth of iron intake per day. The calcium and zinc levels found in our research were higher than those in a previous study on Dadiah micronutrient analysis from Agam and Tanah Datar district, West Sumatra. Dadiah Agam contained $190.54 \mathrm{mg}$ of calcium and $0.7 \mathrm{mg}$ of zinc, whereas Dadiah Tanah Datar had $247.93 \mathrm{mg}$ of calcium and $0.9 \mathrm{mg}$ of zinc in the same amount. However, there were no data on iron concentration in the Agam and Tanah Datar dadiah [25]. The difference in micronutrient content between these studies was probably due to differences in sources of buffalo milk as the main ingredient in Dadiah production. The quality, quantity, and composition of nutrition given to the buffalo affected the chemical characteristics of its milk [35].

Table 2: Micronutrient content and total LAB of Indonesian dadiah, mango dadiah pudding and chocolate Dadiah pudding

\begin{tabular}{llll}
\hline Content & Dadiah (D) & Mango Dadiah pudding (MD) & $\begin{array}{l}\text { Chocolate Dadiah } \\
\text { pudding (CD) }\end{array}$ \\
\hline Micronutrient & & & \\
$\mathrm{Ca}(\mathrm{mg} / 100 \mathrm{~g})$ & 347.98 & 276.61 & 279.29 \\
$\mathrm{Zn}(\mathrm{mg} / 100 \mathrm{~g})$ & 4.87 & 3.75 & 6.31 \\
$\mathrm{Fe}(\mathrm{mg} / 100 \mathrm{~g})$ & 6.53 & 6.60 & 9.39 \\
Total LAB (CFU/ml) & $6.4 \times 10^{9}$ & $6.1 \times 10^{9}$ & $2.4 \times 10^{9}$ \\
\hline LAB: Lactic acid bacteria. & & &
\end{tabular}

The original Dadiah (D) had different compositions of calcium, zinc, and iron levels as compared to those in mango Dadiah pudding (MD) and chocolate Dadiah pudding (CD), as presented in Table 2. These differences might have resulted from the ingredients and the process while making Dadiah pudding. Modifying the original Dadiah into Dadiah pudding reduced calcium level from $347.98 \mathrm{mg}$ in Dadiah to $276.61 \mathrm{mg}$ in MD and $279.29 \mathrm{mg}$ in CD. Calcium concentration was known to be closely related to the acidification step [36]. The highest concentration of zinc ( $\mathrm{Zn}$ ) and iron ( $\mathrm{Fe}$ ) was found in $\mathrm{CD}$ as compared to the original Dadiah (D) and MD may be influenced by the chocolate ingredient contained in the pudding powder. Chocolate is known as a source of zinc and provides some of iron [37]. Mango and CD may help meet around one-fifth of the daily calcium intake for pregnant women based on The Indonesian RDA. MD may cover a pregnant woman's daily requirement for one-third of zinc and one-fourth of iron intake, whereas CD may provide half of zinc and one-third of iron [34]. At present, the $\mathrm{WHO}$ recommends supplementation with $1500 \mathrm{mg} /$ day of calcium, $15 \mathrm{mg} /$ day of zinc, and $30 \mathrm{mg} /$ day of iron [38], [39]. Thus, consumption of Dadiah pudding might help pregnant women through their pregnancy by achieving the minimum intake of these required micronutrients.

\section{Macroscopic and total LAB count}

The original Dadiah samples used in this study had a white color, creamy taste, smooth texture, and milky aroma. According to Surono [29], good quality of Dadiah has a cream-white color, smooth and shiny surface, uniform consistency, pleasant aroma, and sour taste and is free from cracks and air bubbles. Different Dadiah-producing areas resulted in significant differences in color, taste, texture, and general acceptance but not in the aroma. According to Helmizar [31], Dadiah originated from Tanah Datar had a slightly white in color and a less acidic taste and a soft texture compared to Dadiah Agam. This may be due to the quality of buffalo milk, which was affected by animal feed. The buffalos from Tanah Datar were fed with banto grass and Nepal stone or limestone that contains calcium carbonate $\left(\mathrm{CaCO}_{3}\right)$ as food supplements. By contrast, Agam buffalos were fed with cogon grass (Imperata cylindrica) that contained several acidic substances such as chlorogenic acid, oxalic acid, malic acid, and citric acid. Moreover, the type of bamboo tube used to package the Dadiah also affected its macroscopic. Lapoh bamboo used as a container of Tanah Datar dadiah was smaller and thinner than Talang bamboo used to pack Agam dadiah. This bamboo was lower in porosity so that Tanah Datar dadiah's water content was higher than that of Agam and resulted in a soft texture [19].

As compared to the original Dadiah, the color of Dadiah pudding depends on the kind of the pudding powder used, peach color for MD, and light brown for $C D$. Dadiah pudding had a thinner consistency, and the milk aroma was not too strong because of the mango and chocolate flavor of pudding powder. Change in texture can be caused by the process of making Dadiah pudding by adding pudding powder and water to the original Dadiah.

Cultures were performed on MRSA, a selective medium that promotes the growth of lactic acid-producing bacteria. All samples indicated that the single colonies of original Dadiah (D), MD, and CD were white beige and had a smooth round shape, a convex surface, and a 1-2 $\mathrm{mm}$ diameter (Figure 2a). Our results are similar to the characteristics of isolates from Dadiah Lintau in studies by Amelia et al. [28] and

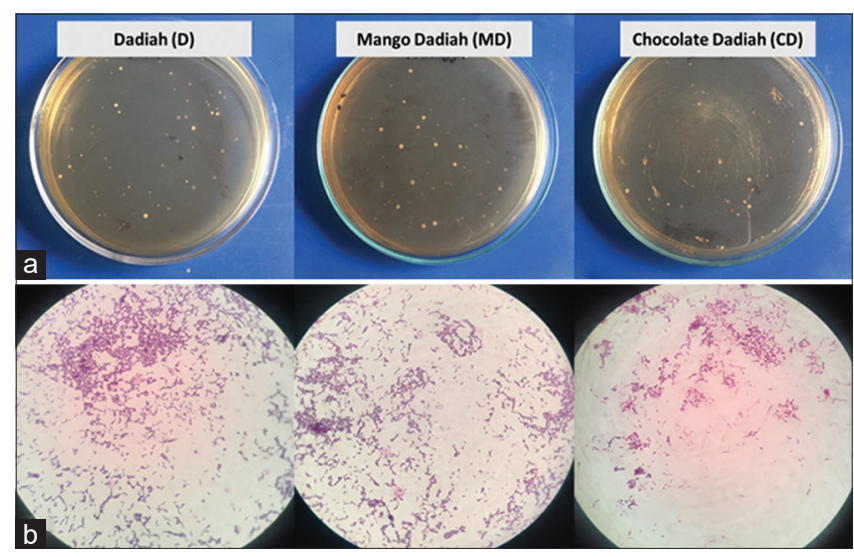

Figure 2: (a) Isolated colonies of lactic acid bacteria from samples cultured in de Man, Rogosa, and Sharpe Agar medium after incubation for $48 \mathrm{~h}$ at $37^{\circ} \mathrm{C}$. (b) Gram stain results of samples showing Gram (+), non-motile rod and cocci bacteria 
Purwati et al. [40] that found a round, edge slick, and convex shape; a white-beige color; and a $1.8 \mathrm{~mm}$ in diameter.

As a probiotic product, LAB in Dadiah has to be consumed alive and in an adequate amount to have a health benefit on the host [41]. The total colonies of LAB in Dadiah (D), MD, and CD are presented in Table 2. Our study found that total $L A B$ in the original Dadiah $\left(6.4 \times 10^{9} \mathrm{CFU} / \mathrm{ml}\right)$ was almost the same as those in MD $\left(6.1 \times 10^{9} \mathrm{CFU} / \mathrm{ml}\right)$, whereas they were reduced $\left(2.4 \times 10^{9} \mathrm{CFU} / \mathrm{ml}\right)$ in chocolate mango pudding. A decrease of $62.5 \%$ of total $L A B$ in $C D$ as compared to the original Dadiah may be due to the chocolate powder used as the additional ingredient in pudding powder. According to Peng et al. [42], the addition of cocoa into dairy products could improve the growth of Lactobacillus, common milk resident bacteria. However, these results indicated that modifying the original Dadiah into Dadiah pudding by adding various ingredients and certain manufacturing processes maintained the total viability of LAB. All samples were potential sources of probiotic food according to $\mathrm{FAO} / \mathrm{WHO}$ because of concentrations were $10^{9} \mathrm{CFU} / \mathrm{ml}$, which met the minimum requirements of $10^{6} \mathrm{CFU} / \mathrm{ml}$ [43].

LAB in Dadiah could be obtained mainly from raw fresh buffalo milk, bamboo tubes, or banana leaves [44]. The previous studies demonstrated that different sources of buffalo milk, animal feed, and various stages of the natural fermentation process resulted in different amounts of $L A B$ in Dadiah; 1.3- $1.7 \times 10^{8} \mathrm{CFU} / \mathrm{g}$ in Dadiah from Bukittinggi [20], $3.81 \times 10^{7} \mathrm{CFU} / \mathrm{g}$ in Dadiah from Lintau [45], $1.9 \times 10^{7} \mathrm{CFU} / \mathrm{g}$ in Dadiah from Tanah Datar, and $4.6 \times 10^{6} \mathrm{CFU} / \mathrm{g}$ in Dadiah from Agam [19]. Another study found that $1.42 \times 10^{8}$ to $3.80 \times 10^{8} \mathrm{CFU} / \mathrm{g}$ viable $L A B$ in Dadiah originated from Bukittinggi and Padang Panjang [42]. The current result indicate that total LAB Dadiah air dingin was $8.0 \times 10^{8} \mathrm{CFU} / \mathrm{g}$ [46], and $7.1 \times 10^{10} \mathrm{CFU} / \mathrm{ml}$ total LAB Dadiah originated from Tanjung Bonai, Lintau Buo Utara, Tanah Datar District, West Sumatra [28]. A study reported the beneficial effects of probiotics to include improvement of intestinal health [47], metabolic efficiency [48], and the immune response [20], [23]. A bamboo tube used as a container for Dadiah also affected the growth of LAB. Talang bamboo used for Agam Dadiah was higher in porosity compared to Lapoh bamboo used for Tanah Datar Dadiah made total LAB of Agam Dadiah $\left(4.6 \times 10^{6}\right)$ was lower than Tanah Datar Dadiah $\left(1.9 \times 10^{7}\right)$ [19].

The growth of Dadiah bacteria was influenced by not only the animal feed, location, or method of fermentation but duration and temperature. According to Surono [29], our study used only 48-h fermented buffalo milk at $20^{\circ} \mathrm{C}-45^{\circ} \mathrm{C}$ to get the optimum growth of $L A B$ and its nutrient value [29]. Our research also indicated that reducing the pudding temperature to $\pm 60^{\circ} \mathrm{C}-70^{\circ} \mathrm{C}$, before mixing it with the original Dadiah while making Dadiah pudding, helped maintain total $L A B$. This might be due to the thermotolerant capacity of some $L A B$ to survive in thermal treatment, heating at $70^{\circ} \mathrm{C}$ in $60 \mathrm{~min}[49]$.

\section{Morphology identification}

Colonies from all of the samples with the surrounding clear zone were randomly selected on each plate. From the Gram staining, LAB colonies were characterized by a non-motile rod and cocci Grampositive bacteria (Figure $2 b$ ). Our results were similar to those of studies by Purwati et al. [40] and Amelia et al. [28], which indicated that the Gram- positive bacteria in Dadiah originated from Lintau, Tanah Datar Regency, West Sumatra. According to Amelia et al. [28], the LAB in Dadiah appeared as the rodshaped Gram-positive bacteria. However, Purwati et al. [40] found that the LAB were cocci and bacilli. Surono [27] also found that all bacteria in Dadiah from Agam and Tanah Datar districts, West Sumatra were Gram-positive.

\section{Conclusion}

Manufacturing the original Dadiah into Dadiah pudding with the addition of certain ingredients, and processes has been proved to change the concentration of calcium, zinc, and iron, and maintain the total LAB. There were $347.98,276.61$, and $279.29 \mathrm{mg}$ of calcium; $4.87,3.75$ and $6.31 \mathrm{mg}$ of zinc; and 6.53 , 6.60 , and $9.39 \mathrm{mg}$ of iron in $100 \mathrm{~g}$ of original Dadiah and mango and CD. As a probiotic food, it also found $6.4 \times 10^{9}$, $6.1 \times 10^{9}$, and $2.4 \times 10^{9} \mathrm{CFU} / \mathrm{ml}$ total LAB in the original Dadiah and mango and CD. Therefore, Dadiah pudding can be a good choice as a food supplementation that is beneficial for prenatal supplementation and pregnancy outcomes. Consuming Dadiah pudding may facilitate attaining healthy pregnancy and optimal golden period outcomes. Dadiah pudding also has the potential to be a healthy food for daily consumption.

\section{Acknowledgment}

The authors would like to thank Universitas Indonesia for funding this research through PUTI Grant with contract number NKB-3239/UN2. RST/HKP.05.00/2020. We also thank the Head of Microbiology Laboratory, Faculty of Medicine, Universitas Andalas, and Head of Industrial Research and Standardization Center, Padang, West Sumatera, Indonesia. 


\section{References}

1. Farias PM, Marcelino G, Santana LF, de Almeida EB, Guimarães RC, Pott A, et al. Minerals in pregnancy and their impact on child growth and development. Molecules. 2020;25(23):5630. https://doi.org/10.3390/molecules25235630 PMid:33265961

2. Abu-Ouf NM, Jan MM. The impact of maternal iron deficiency and iron deficiency anemia on child's health. Saudi Med J. 2015;36(2):146-9. https://doi.org/10.15537/smj.2015.2.10289 PMid:25719576

3. Nnam NM. Improving maternal nutrition for better pregnancy outcomes. Proc Nutr Soc. 2015;74:454-9. https://doi. org/10.1017/s0029665115002396 PMid:26264457

4. Wang $\mathrm{H}, \mathrm{Hu} Y \mathrm{~F}$, Hao JH, Chen $\mathrm{YH}$, Su PY, Wang $\mathrm{Y}$, et al. Maternal zinc deficiency during pregnancy elevates the risks of fetal growth restriction: A population-based birth cohort study. Sci Rep. 2015;5:11262. https://doi.org/10.1038/srep11262 PMid:26053136

5. Aryastami NK, Shankar A, Kusumawardani N, Besral B Jahari $A B$, Achadi $E$. Low birth weight was the most dominant predictor associated with stunting among children aged 12-23 months in Indonesia. BMC Nutr. 2017;3:16. https://doi. org/10.1186/s40795-017-0130-x

6. Kumar A, Kaur S. Calcium: A nutrient in pregnancy. J Obstet Gynaecol India. 2017;67(5):313-8. PMid:28867880

7. Aji AS. Yerizel E. Desmawati D. Lipoeto NI. Low maternal Vitamin $D$ and calcium food intake during pregnancy associated with place of residence: A cross-sectional study in West Sumatran women, Indonesia. Open Access Maced J Med Sci. 2019;7(17):2879-85. https://doi.org/10.3889/oamjms.2019.659 PMid:31844453

8. Bardosono S. Maternal micronutrient deficiency during the first trimester among Indonesian pregnant women living in Jakarta. eJ Kedokteran Indones. 2016;4:3-8. https://doi.org/10.23886/ ejki.4.6281.76-81

9. World Health Organization: Nutritional Anaemias: Tools for Effective Prevention and Control. Geneva: World Health Organization; 2017.

10. Robertson RC. The gut microbiome in child malnutrition. Nestle Nutr Inst Workshop Ser. 2020;93:133-44. PMid:31991429

11. Subramanian $S$, Huq $S$, Yatsunenko $T$, Haque $R$, Mahfuz M, Alam MA, et al. Persistent gut microbiota immaturity in malnourished Bangladeshi children. Nature. 2014;510(7505):417-21. https://doi.org/10.1038/nature13421 PMid:24896187

12. Rackaityte E, Halkias J, Fukui EM, Mendoza VF, Hayzelden C, Crawford ED, et al. Viable bacterial colonization is highly limited in the human intestine in utero. Nat Med. 2020;26(4):599-607. https://doi.org/10.1038/s41591-020-0761-3 PMid:32094926

13. Younge N, McCann JR, Ballard J, Plunkett C, Akhtar S, AraújoPérez $\mathrm{F}$, et al. Fetal exposure to the maternal microbiota in humans and mice. JCI Insight. 2019;4(19):e127806. https://doi. org/10.1172/jci.insight.127806 PMid:31479427

14. Chen Y, Li Z, Tye KD, Luo H, Tang X, Liao Y, et al. Probiotic supplementation during human pregnancy affects the gut microbiota and immune status. Front Cell Infect Microbiol. 2019;9:254. https://doi.org/10.3389/fcimb.2019.00254 PMid:31380297
15. Rothschild D, Weissbrod O, Barkan E, Kurilshikov A, Korem T, Zeevi D, et al. Environment dominates over host genetics in shaping human gut microbiota. Nature. 2018;555(7695):210-5. https://doi.org/10.1038/nature25973 PMid:29489753

16. Mach N, Clark A. Micronutrient deficiencies and the human gut microbiota. Trends Microbiol. 2017;25(8):607-10. https://doi. org/10.1016/j.tim.2017.06.004 PMid:28645724

17. National Standardization Board. Indonesian National Standard 2981:2009. Yogurt. National Standardization Board. 2009.

18. Codex Alimentarius Commission. The Codex Alimentarius Commission. Milk and Milk Products. Rome, Italy: Codex Alimentarius Commission; 2011. https://doi.org/10.1093/ law: epil/9780199231690/e1857

19. Helmizar H, Yuswita E, Putra AE. Analysis of the nutrients and microbiological characteristics of the Indonesian dadih as a food supplementation. Glob J Health Sci. 2019;11:155161. https:// doi.org/10.5539/gjhs.v11n1p155

20. Arasj F. Pengaruh pemberian dadih (susu kerbau fermentasi) melalui makanan tambahan terhadap status gizi kejadian diare dan ispa anak pendek (stunted) usia 14 tahun studi dilakukan di kenagarian kototangah kecamatan tilatang kamang Kabupaten Agam Sumatera Barat [The effect of giving curd (fermented buffalo milk) through supplementary food on nutritional status incidence of diarrhea and ARI in stunted children aged 14 years]. The study was conducted in kenagarian koto tangah tilatang kamang district. J IImu Kesehatan. 2014;1:18. https:// doi.org/10.32883/hcj.v3i3.36

21. Balqis R, Putra AE, Utama BI, Helmizar H. Pengaruh pemberian dadih dengan perubahan jumlah Lactobacillus fermentum pada feses ibu hamil (Effect of curd administration with changes in the amount of Lactobacillus fermentum in pregnant mother's stool). Andalas J Health. 2018;7:42-6. https://doi.org/10.25077/ jka.v7i0.872

22. Helmizar H, Surono IS, Saufani IA. Development of dadih powder as a complementary food to prevent children from stunting in West Sumatra Indonesia. IOP Conf Ser Earth Environ Sci. 2020;583:16. https://doi.org/10.1088/1755-1315/583/1/012027

23. Prakoeswa CRS, Herwanto N, Prameswari R, Astari L, Sawitri S, Hidayati AN, et al. Lactobacillus plantarum IS-10506 supplementation reduced SCORAD in children with atopic dermatitis. Benef Microbes. 2017;8(5):833-40. https://doi. org/10.3920/bm2017.0011 PMid:29022387

24. Surono IS, Martono PD, Kameo S, Suradji EW, Koyama H. Effect of probiotic L. plantarum IS-10506 and zinc supplementation on humoral immune response and zinc status of Indonesian preschool children. J Trace Elem Med Biol. 2014;28(4):465-9. https://doi.org/10.1016/j.jtemb.2014.07.009 PMid:25183688

25. Helmizar $H$, Surono IS. Characteristics of amino acid micronutrient and probiotic isolated from dadih and their benefits for pregnant mothers and outcomes in West Sumatra Indonesia. Glob J Health Sci. 2020;12:116123. https://doi.org/10.5539/ gjhs.v12n1p116

26. Purwandhani SN, Utami T, Millati R, Rahayu ES. Isolation characterization and screening of folateproducing bacteria from traditional fermented food (dadih). Int Food Res J. 2018;25:566-72.

27. Markowiak P, Śliżewska K. Effects of probiotics prebiotics and synbiotics on human health. Nutrients. 2017;9(9):1021. https:// doi.org/10.3390/nu9091021 PMid:28914794

28. Amelia R. Philip K. Pratama YE. Purwati E. Characterization and probiotic potential of lactic acid bacteria isolated from dadiah sampled in West Sumatra. Food Sci Technol. 2020;17:1-7. 
https://doi.org/10.1590/fst.30020

29. Surono IS. Indonesian dadih. In: Puniya AK, editors. Fermented Milk and Dairy Products. United States: CRC Press; 2016. p. 377-99.

30. Maryana TA. Organoleptik Dan Daya Simpan Dadih Susu Sapi Dengan Inovasi Bambu Kering Dan Suhu Yang Berbeda Selama Penyimpanan (Organoleptic and Shelf Life of Cow's Milk Curd with Dry Bamboo Innovation and Different Temperatures during Storage), Thesis Universitas Muhammadiyah Surakarta Surakarta; 2014. https://doi.org/10.29244/jipthp.6.2.73-80

31. Helmizar H. Panduan Konsumsi Dadih Sebagai Suplementasi Gizi Ibu Hamil (Guide to the Consumption of Curd as a Nutritional Supplement for Pregnant Women). Padang: Andalas University Press; 2019.

32. Risfaheri US. Pengembangan Dadih Sebagai Pangan Fungsional Probiotik Asli Sumatera Barat (Improvement of Dadih as an Indigenous Probiotic Functional Food of West Sumatera). J Litbang Pertanian. 2013;32:2029. https://doi. org $/ 10.25077 / 0230100$

33. Lipoeto NI. Agus Z. Oenzil F. Wahlqvist M. Wattanapenpaiboon N. Dietary intake and the risk of coronary heart disease among the coconut-consuming Minangkabau in West Sumatra Indonesia. Asia Pac J Clin Nutr. 2004;13(4):377-84. https://doi. org/10.1046/j.1440-6047.2001.00201.x PMid:15563444

34. Ministry of Health of Republic of Indonesia: Peraturan Menteri Kesehatan Republik Indonesia No. 28 Tahun 2019: Angka Kecukupan Gizi Yang Dianjurkan Untuk Masyarakat Indonesia (Regulation of the Minister of Health of the Republic of Indonesia No. 28 of 2019: The Recommended Nutritional Adequacy Rate for the Indonesian Society). Jakarta: Ministry of Health of Republic of Indonesia; 2019. https://doi.org/10.18311/ jeoh/2020/26134

35. Khedkar CD, Kalyankar SD, Deosarkar SS. Buffalo milk. In: Caballero B, Finglas PM, Toldrá F, editors. Encyclopedia of Food and Health. Amsterdam, Netherlands: Elsevier Ltd.; 2016. https://doi.org/10.1016/b978-0-12-384947-2.00093-3

36. Gaucheron F. Milk and dairy products: A unique micronutrient combination. J Am Coll Nutr. 2011;30 Suppl 1:400S-9S. PMid:22081685

37. Cinquanta L, di Cesare $C$, Manoni R, Piano A, Roberti $P$, Salvatori G. Mineral essential elements for nutrition in different chocolate products. Int J Food Sci Nutr. 2016;67(7):773-8. https://doi.org/10.1080/09637486.2016.1199664 PMid:27346251

38. World Health Organization. Guideline: Calcium Supplementation in Pregnant Women. Geneva, Switzerland: World Health Organization; 2013.

39. World Health Organization. WHO Antenatal care Recommendations for a Positive Pregnancy Experience Nutritional Interventions Update: Multiple Micronutrient
Supplements during Pregnancy. Geneva, Switzerland: World Health Organization; 2020. https://doi.org/10.1037/ e418252004-001

40. Purwati E, Hellyward J, Yuherman, Purwanto H, Hartini RP. Isolation characterization and identification of DNA's lactic acid bacteria (lab) of dadih lintau (Tanah Datar district) which is antibiotic resistance. Int J Adv Eng Technol. 2018;6:2831.

41. FAO/WHO: Probiotics in Food: Health and Nutritional Properties and Guidelines for Evaluation. Rome, Italy: WHO and FAO; 2006.

42. Peng M, Aryal U, Cooper B, Biswas D. Metabolites produced during the growth of probiotics in cocoa supplementation and the limited role of cocoa in hostenteric bacterial pathogen interactions. Food Control. 2015;53:124-33. https://doi. org/10.1016/j.foodcont.2015.01.014

43. Kechagia M, Basoulis D, Konstantopoulou S, Dimitriadi $D$, Gyftopoulou K, Skarmoutsou N, et al. Health benefits of probiotics: A review. ISRN Nutr. 2013;2013:481651. https://doi. org/10.5402/2013/481651

PMid:24959545

44. Surono IS. Hosono A. Performance of dadih cultures in fluid milk application at low temperature storage. Asian Australas J Anim. 2000;13:495-8.

45. Sumarni IP, Endang P, Salam NA. Pengaruh Efektifitas Bakter Asam Laktat Terhadap Kualitas Mikrobiologis Dan Daya Simpan Dadiah di Beberapa Daerah di Sumatera Barat (Effect of the Effectiveness of Lactic acid Bacteria on the Microbiological Quality and Storage Capacity of Dadiah in Several Areas in West Sumatra), Thesis Andalas University Padang; 2011.

46. Harun H, Wirasti Y, Purwanto B, Purwati E. Characterization of lactic acid bacteria and determination of antimicrobial activity in dadih from Air Dingin Alahan Panjang District Solok Regency West Sumatera. Syst Rev Pharm. 2020;11(3):583-6.

47. Surono IS, Koestomo FP, Novitasari N, Zakaria FR, Yulianasari, Koesnandar. Novel probiotic Enterococcus faecium IS-27526 supplementation increased total salivary slgA level and bodyweight of preschool children: A pilot study. Anaerobe. 2011;17(6):496-500. https://doi.org/10.1016/j. anaerobe.2011.06.003

PMid:21763445

48. Kusumo PD, Bela B, Wibowo H, Munasir Z, Surono IS. Lactobacillus plantarum IS-10506 supplementation increases faecal slgA and immune response in children younger than two years. Benef Microbes. 2019;10(3):245-52. https://doi. org/10.3920/bm2017.0178

PMid:30694099

49. PérezChabela MD, Totosaus A, Guerrero I. Evaluation of thermotolerant capacity of lactic acid bacteria isolated from commercial sausages and the effects of their addition on the quality of cooked sausages. Food Sci Technol. 2008;28(1):132-8. https://doi.org/10.1590/s0101-20612008000100019 